\title{
Perancangan Sistem Informasi Menejemen Bengkel Di Gama Auto Service
}

\author{
Deni Rohnadi \\ Magister Teknik Industri, Fakultas Teknologi Industri, Universitas Islam Indonesia \\ Jalan Kaliurang KM 14,5 Sleman, Daerah Istimewa Yogyakarta 55584, Indonesia \\ E-Mail :deni.rnd@gmail.com
}

\begin{abstract}
ABSTRAK
Penelitian ini bertujuan untuk (1) Memberikan analisa kebutuhan Sistem Informasi proses kerja Divisi Servis di Bengkel Gama Auto Service. (2) Memberikan konsep rancangan Sistem Informasi Manejemen proses kerja Divisi Servis di Bengkel Gama Auto Service. Langkah-langkah penelitian ini adalah (1) Requirements Planning (2) Design Workshop yaitu perancangan sistem informasi. Hasil analisa data dirumuskan perancangan sistem informasi tentang (1) Informasi proses kerja mekanik kepada servis advisor, (2) Informasi penggantian suku cadang kepada servis advisor dan admin suku cadang, (3) Informasi tambahan pekerjaan mekanik kepada servis advisor. Kemudian disusun Desain Sistem Informasi tentang Kontrol Pekerjaan Bengkel dan Kinerja Mekanik. Adanya Sistem informasi kontrol pekerjaan harapannya dapat menjadi solusi permasalahan terhambatnya informasi pekerjaan dan dapat mempercepat informasi dari beberapa bagian di Divisi Servis. Selain itu secara internal, komunikasi antar divisi yang baik dan terkontrol akan membangun hubungan yang solid antar divisi dan dapat meningkatkan pendapatan perusahaan. Sistem informasi kontrol pekerjaan komunikasi dengan pelanggan juga akan lebih cepat sehingga dapat meningkatkan pelayanan konsumen serta menghindari salah informasi terhadap konsumen. Sehingga dapat mengurangi tingkat complain karena komunikasi.
\end{abstract}

Kata kunci: Bengkel Mobil, Manajemen Bengkel, Sistem Informasi Manajemen.

\section{Design Management Information System of Workshop at Gama Auto Service}

\begin{abstract}
This study aims to (1) Provide an analysis of the Information System requirements of the Service Division's work process at the Gama Auto Service Workshop. (2) Providing the design concept of the work process Management Information System of the Service Division at the Gama Auto Service Workshop. The steps of this research are (1) Requirements Planning (2) Design Workshop, namely the design of information systems. From the results of data analysis formulated a system design information about (1) Information on mechanical work processes to service advisors, (2) Information on replacement of parts to service advisors and parts admin, (3) Additional information on mechanical work to service advisor. Then the Information System Design is prepared about Workshop Job Control and Mechanical Performance. The existence of job control information systems is expected to be a solution to the problem of delays in job information and can speed up information from several parts in the Service Division. In addition, internally, good and controlled communication between divisions will build solid relationships between divisions and can increase company revenue. With the information system control the work of communication with customers will also be faster so that it can improve customer service and avoid misinformation of consumers. So that it can reduce the level of complaints due to communication.
\end{abstract}

Keywords: Car Workshop, Workshop Management, Management Information System.

\section{Pendahuluan}

Pesatnya perkembangan teknologi informasi dan komunikasi atau Information and Communication Technology (ICT), telah merambah berbagai bidang kehidupan (Ward \& Peppard, 2003). Perkembangan ICT setiap 
orang dapat mengolah, memproduksi serta mengirimkan ataupun menerima segala bentuk pesan komunikasi dimana saja dan kapan saja, seolaholah tanpa mengenal batasan ruang dan waktu (Nurdiana, 2009).

Desain atau perancangan menjadi faktor yang menentukan model atau pola sistem informasi yang akan diterapkan. Informasi merupakan kebutuhan bagi menejemen dalam pengembilan keputusan (Riyadi, 2012). Sistem informasi menjadi sarana untuk mempermudah kinerja terutama sebagai data base semua data yang terintegrasi dan dapat diakses sesuai keperuntukannya sesuai dengan divisi yang mempunyai wewenangnya masing-masing. Hal ini menyebabkan sistem menjadi lebih baik (Winardi, 2017). Sistem yang lebih baik dapat menyajikan informasi yang tepat dan akurat, sehingga meminimalisir terjadinya permasalahan dan kesalahan (Ramadina, 2015).

Kemudian data base konsumen yang lengkap menjadi bagian yang penting sebagai industri jasa layanan yang merupakan sumber pendapatan harus juga mudah diakses oleh marketing untuk dijadikan target pemasaran.

Bengkel Gama Auto Service salah satu bengkel mobil yang sudah berjalan hampir delapan tahun sudah memiliki SDM dengan jumlah karyawan 16 orang dan masingmasing sudah mempunyai peran dan tugasnya. Sistem informasi yang ada di Bengkel Gama Auto Service sudah berjalan hanya ada beberapa kendala yang dihadapi karena beberapa administrasi masih dikerjakan secara catatan tertulis menggunakan form-form misalnya work order belum terintegrasi dalam sebuah sistem informasi sehingga ada beberapa poin pekerjaan menjadi dua kali kerja. Menurut Jogiyanto, (1999):"Sistem adalah kumpulan dari elemen-elemen yang saling berinteraksi untuk mencapai suatu tujuan". Sehingga sistem informasi harus saling terhubung dan terintegrasi. Bengkel dengan jumlah stall servis sampai 16 mobil membutuhkan adanya perancangan sistem informasi yang terintegrasi agar dapat mempermudah dalam pemantauan perkembangan usaha. Menurut
Penelitian yang telah dilakukan oleh (Desy F.T dan Lia Yong, 2010) tujuan penelitian adalah untuk merancang sistem pengolahan transaksi yang menggunakan basis data sehingga dapat mempermudah dalam pemantauan perkembangan usaha dan memudahkan dalam menganalisis laporan. Selain itu dengan menggunan sistem informasi dalam proses kerja di divisi servis menjadi salah satu strategi bisnis dalam menghadapi persaingan usaha yang semakin ketat di dunia perbengkelan khususnya di Yogyakarta. Mengutip penelitian (Sebayang, Desi. 2015). salah satu bisnis atau usaha yang juga merasakan ketatnya persaingan saat ini adalah bisnis bengkel perawatan dan perbaikan mobil. Persaingan yang semakin ketat tersebut ditandai dengan makin banyaknya bengkel-bengkel bermunculan.

Berdasarkan pengamatan sistem informasi yang ada di Gama Auto Service sudah mencakup proses transaksi dan work order atau surat perintah kerja. Ada beberapa hal yang terjadi pada flow process produksi di bengkel yaitu proses konfirmasi terjadi secara manual menggunakan lembar work order, sehingga secara acak terjadi proses delay karena konfirmasi pekerjaan pada saat penggantian komponen dan konfirmasi pelanggan menunggu supervisor mengecek kendaraan, dan pada kondisi full order terkendala proses jarak front office dengan bengkel yang cukup jauh, yang terjadi proses waktu yang lama menjadikan time rate pekerjaan lebih lama. Kondisi tertentu menyebabkan kualitas pekerjaan menjadi turun dikarenakan kontrol kualitas yang tidak berjalan cepat. Menurut Daryanto (2006), tujuan utama dari pembagian tingkat pemeliharaan ini adalah untuk membuat pekerjaan pemeliharaan lebih rasional sehingga lebih ekonomis serta rendah biaya pelaksanaanya. Maka dari itu diperlukan analisis untuk mendapatkan sistem kerja yang lebih efisien. Menurut Martin T. Teiseran (2003), konsep perawatan atau pemeliharaan mobil sudah dikenal sejak pertengahan abad 20. Kata pemeliharaan itu sendiri berasal dari bahasa Inggris 
"Maintenance". Maintenance itu sendiri berasal dari bahasa latin "Manutentione" yang berarti merawat dengan tangan.

Beberapa dampak lainnya adalah dengan adanya tambahan waktu karena dua kali kerja informasi flow process tentang kendaraan yang diberikan kepada konsumen menjadi lebih lama sehingga merugikan konsumen. Demikian pemaparan permasalahan yang menjadi pokok bahasan dalam penelitian ini. Adanya temuan permasalahan tersebut diharapakan mendapatkan sebuah rancangan sistem informasi yang dapat memberikan solusi dan bermanfaat unit bisnis Gama Auto Service

Berdasarkan uraian di atas penelitian ini bertujuan untuk memberikan analisa kebutuhan Sistem Informasi proses kerja Divisi Servis di Bengkel Gama Auto Service dan memberikan konsep rancangan Sistem Informasi Manejemen proses kerja Divisi Servis di Bengkel Gama Auto Service. Serta berkontribusi mempermudah analisis laporan dan pemantauan perkembangan usaha.

\section{Metodologi}

Rapid Application Development (RAD) adalah strategi siklus hidup yang ditujukan untuk menyediakan pengembangan yang jauh lebih cepat dan mendapatkan hasil dengan kualitas yang lebih baik dibandingkan dengan hasil yang dicapai melalui siklus tradisional (McLeod, 2002). Pendapat lain RAD merupakan metode iteratif (berulang) untuk mengembangkan sistem dalam working model (model bekerja) mengkonstruksikan sistem pada awal pengembangan bertujuan menetapkan kebutuhan (requirement) pengguna dan selanjutnya diabaikan (Aswati, 2016). Pemaparan konsep yang lebih spesifik lagi dijelaskan oleh Pressman (2005) dalam bukunya, "Software Engineering: A Practition's Approach". Ia mengatakan bahwa RAD adalah proses model perangkat lunak inkremental yang menekankan siklus pengembangan yang singkat.

Penelitian ini menggunakan metode RAD (Rapid Application Development) memodifikasi tahapan atau phase. (Kendall, J.E. \& Kendall, K.E. 2010) ada tiga phase (Gambar 1) yaitu:

1. Requirements Planning (Perencanaan Syarat-Syarat)

2. Design Workshop (Workshop Desain)

3. Implementation (Implementasi)

Penelitian ini fokus pada desain dari sistem informasi sehingga akan memodifikasi dua phase yaitu Requirements Planning dan Design Workshop.

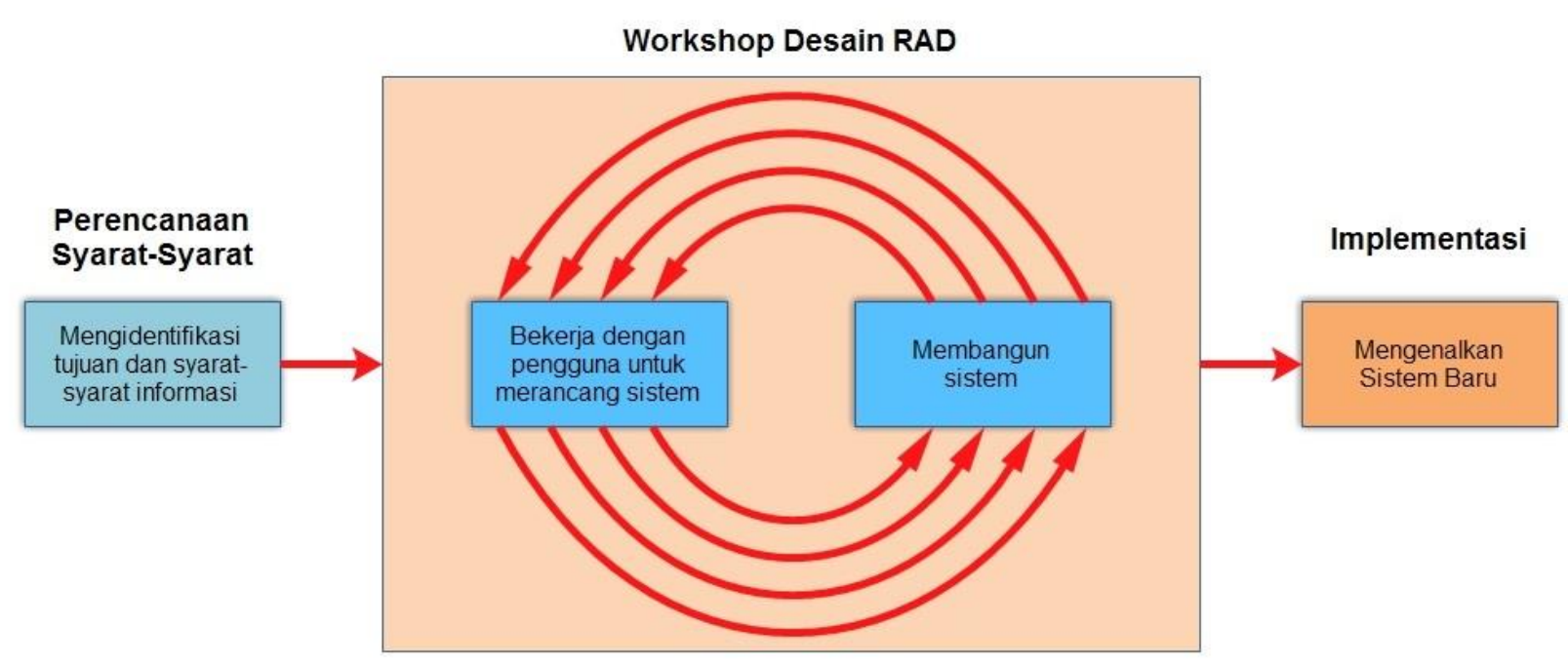

Gambar 1. Siklus RAD 


\section{Requirements Planning}

Requirements planning adalah proses melakukan pengumpulan bahan atau data yang sesuai dengan penelitian yang akan dikembangkan. Masukan dari tahapan ini adalah Dokumentasi dari beberapa prosedur yang sudah berjalan, observasi langsung dan wawancara terhadap pengguna sistem informasi. Metode Observasi adalah pengumpulan data dengan pengamatan langsung pada objek penelitian untuk mendapatkan informasi sebagai bahan dan metode wawancara merupakan tanya jawab langsung pada pihak-pihak yang langsung terlibat atau berkaitan dengan objek yang diteliti (Kurniawan, 2015). Sehingga dalam proses requirements planning akan melakukan pengolahan data dari hasil wawancara yang dilakukan.

\section{Design Workshop}

Proses User Design Phase melewati beberapa tahapan yaitu perencanaan, analisa dan desain atau perancangan. Perancangan sistem informasi yang akan dibangun bersifat object oriented. Data hasil dari tahapan observasi dan metode yang akan digunakan pada tahap user design. Hasil atau Output dari tahapan ini berupa informasi actor dan use case yang terlibat, informasi interaksi antar kelas, actor dan objek, informasi fitur apa saja yang akan diterapkan pada pengembangan sistem informasi selanjutnya serta desain atau gambaran dari aplikasi tersebut.

Berikut ini adalah kelebihan metodologi RAD menurut Marakas (2006):

1. Penghematan waktu dalam keseluruhan fase projek dapat dicapai.

2. RAD mengurangi seluruh kebutuhan yang berkaitan dengan biaya projek dan sumberdaya manusia.

3. RAD sangat membantu pengembangan aplikasi yang berfokus pada waktu penyelesaian projek.

4. Perubahan desain sistem dapat lebih berpengaruh dengan cepat dibandingkan dengan pendekatan SDLC tradisional.

5. Sudut pandang user disajikan dalam sistem akhir baik melalui fungsi-fungsi sistem atau antarmuka pengguna.
6. RAD menciptakan rasa kepemilikan yang kuat di antara seluruh pemangku kebijakan projek.

\section{Hasil dan Pembahasan}

Tahapan yang dilakukan penelitian yaitu perencanaan, analisa dan desain atau perancangan. Tahapan demi tahapan sangat penting dilakukan agar segala permasalahan dapat diindentifikasi secara baik sehingga langkah-langkah mencari rancangan sistem informasi dapat dilakukan secara tepat dan sesuai dengan kebutuhan.

1. Analisis Sistem yang Berjalan

Langkah awal adalah mengumpulkan data. Menurut James A. Obrien (2003), data adalah fakta-fakta atau observasi yang mentah, biasanya mengenai kejadian atau transaksi bisnis. Sistem informasi di Gama Auto Service sudah berjalan, sehingga untuk membantu menganalisa sistem, perlu dilakukan pengamatan beberapa hal yaitu struktur organisasi yang ada, diagram flow proses kerja, serta diagram kinerja sistem informasi yang sudah berjalan. Sehingga dengan pengamatan tersebut dapat dilakukan analisis pengembangan kebutuhan sistem informasi.

\section{a. Struktur Organisasi}

Struktur organisasi di Gama Auto Service dapat dilihat pada Gambar 2.

b. Diagram Alur Kerja

Diagram alur kerja di Gama Auto Service dapat dilihat pada Gambar 3.

Pada tahap ini akan memahami permasalahan yang muncul dan mendefinisikan secara rinci, kemudian menentukan tujuan pembuatan sistem dan mengidentifikasi kendalanya. Penelitian ini mengerucut pada proses kerja di bagian produksi atau proses kerja di bengkel serta flow proses yang terjadi. Beberapa permasalahan telah diidentifikasi terjadi pada proses kerja sehingga beberapa proses kerja mengalami kendala waktu yang lama dan kurang lancarnya aliran informasi pada beberapa bagian. Berikut ini permasalahan pada aliran informasi di bagian produksi atau bengkel: 


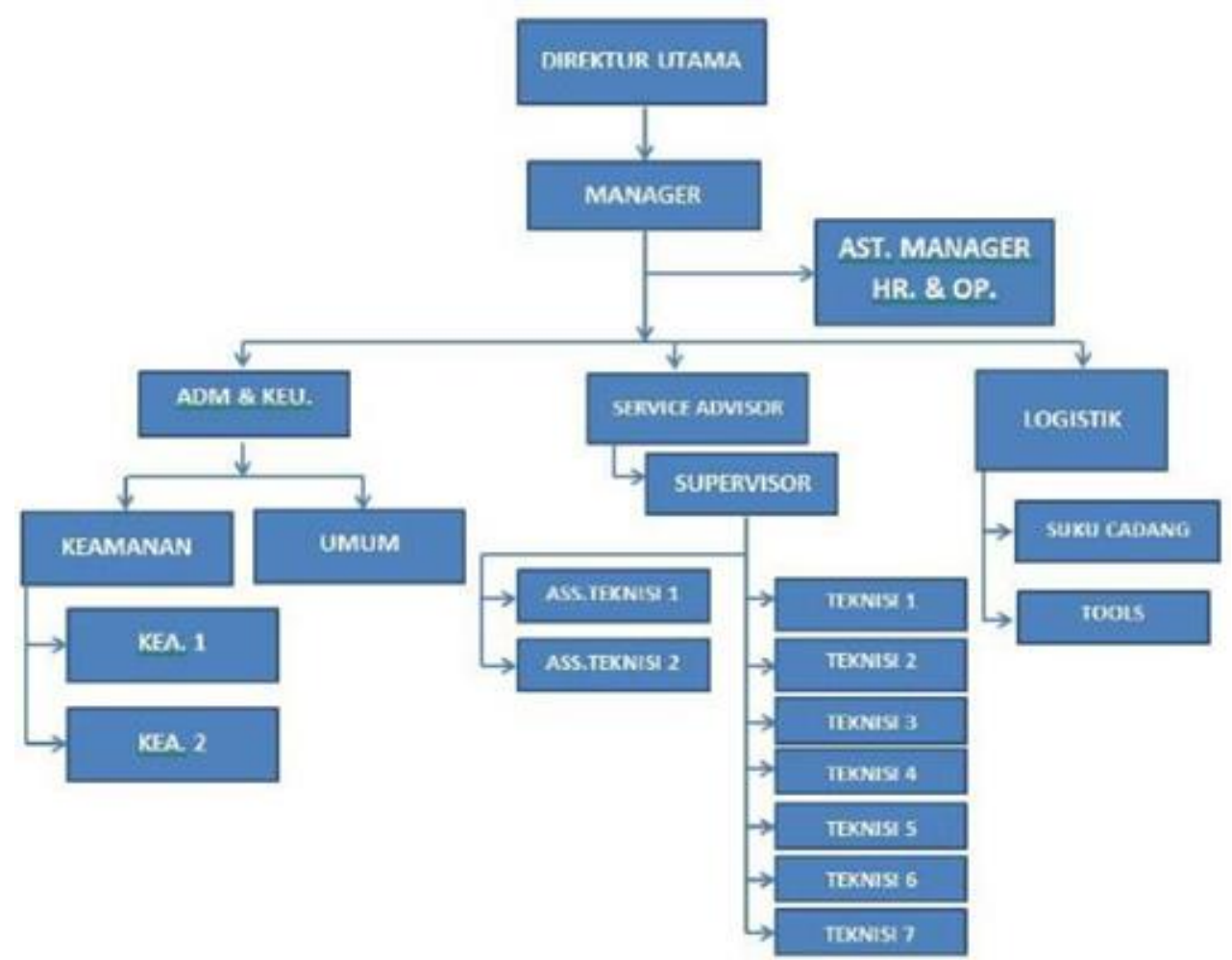

Gambar 2. Struktur Organisasi Gama Auto Service

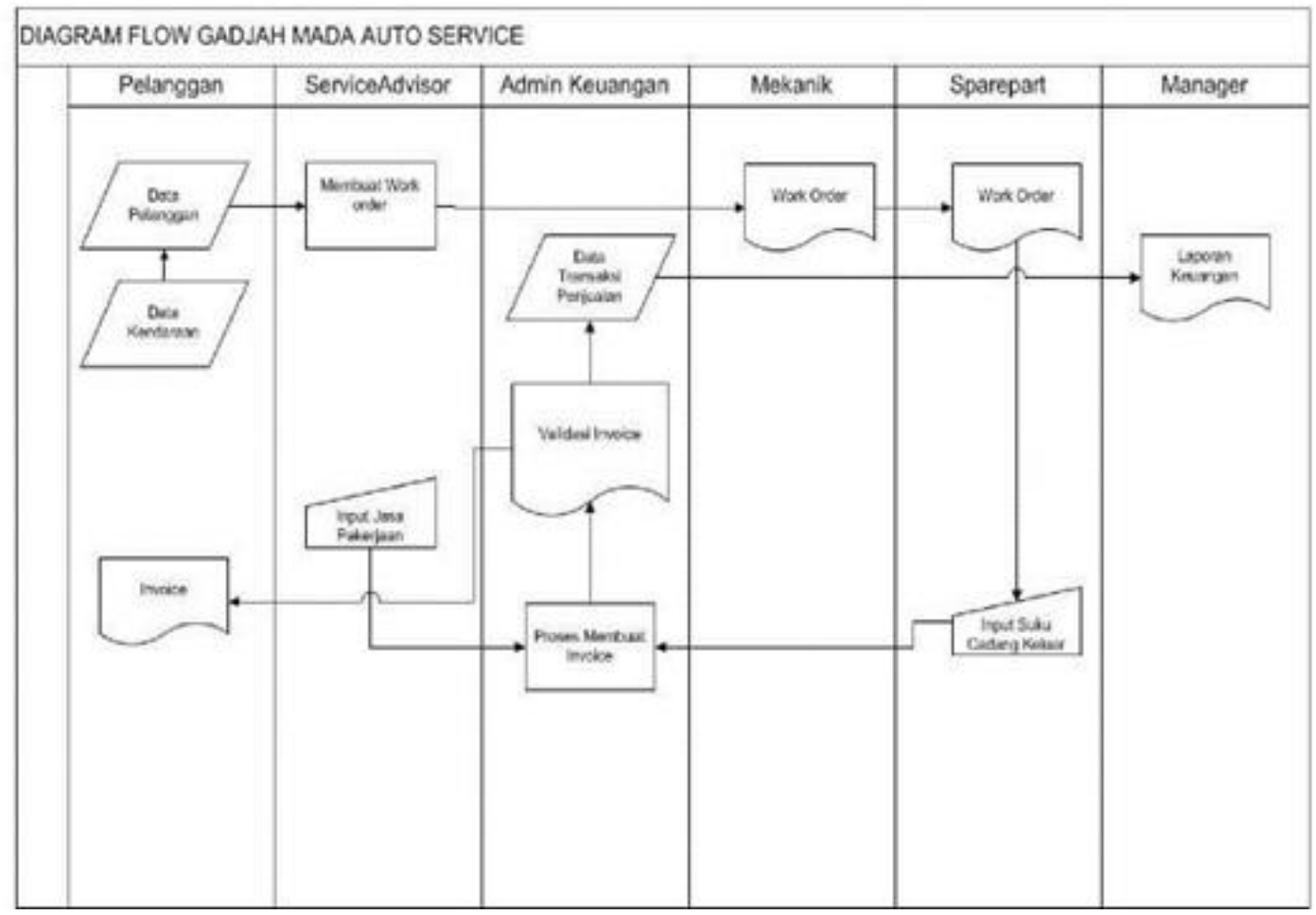

Gambar 3. Diagram Alur Kerja Gama Auto Service 
2. Identifikasi Masalah Analisis

1) Informasi report penggantian suku cadang dari mekanik dan supervisor ke front office untuk diberitahukan kepada konsumen cukup lama, karena teknisi harus berjalan ke front office mengingat letak front office dan bengkel berbeda.

2) Informasi report pekerjaan teknisi masih berjalan dengan catatan tertulis dengan form sehingga teknisi atau supervisor juga harus berjalan ke front office untuk finishing. Ini dikeluhkan oleh kasir karena menunggu penyelesaian nota atau invoice sehingga memperpanjang delay waktu tunggu rekap secara administrasi.

3) Pembagian pekerjaan kepada mekanik hanya berdasarkan antrian, belum melihat beban pekerjaan yang ada, disebabkan supervisor tidak dapat melihat data pendapatan jasa setiap mekanik secara up to date karena pembukuan pendapatan jasa mekanik masih berjalan manual dengan microsoft exel sehingga penentuan pembagian pekerjaan tidak berdasarkan data yang riil sehingga memungkinkan pembagian pekerjaan yang kurang merata.

4) Informasi finishing pekerjaan mekanik masih berjalan secara manual dimana mekanik melaporkan kepada supervisor. Waktu panjang terjadi karena front office meninggalkan tempat kerja datang ke stall service atau mencari supervisor untuk mencari informasi tentang proses pekerjaan. Sehingga memungkinkan terjadi proses menunggu yang lama sampai pekerjaan finishing.

Dari pengamatan masalah di atas ada beberapa kebutuhan sistem informasi yang harus tersedia di bengkel Gama Auto Service sebagai pemecahan masalah-masalah yang sering muncul untuk mempersingkat flow proces produksi dengan menambahkan sistem informasi yaitu sebagai berikut:

1) Informasi proses kerja mekanik kepada servis advisor

2) Informasi penggantian suku cadang kepada servis advisor dan admin suku cadang
3) Informasi tambahan pekerjaan mekanik kepada servis advisor

4) Informasi perolehan jasa mekanik kepada manajer

Keempat poin di atas adalah kebutuhan sistem informasi yang harus ada untuk mengatasi beberapa masalah yang ada di lingkungan produksi dan pelayanan informasi kepada costumers. Secara lengkap solusi permasalahan akan dijawab pada bagian perancangan sistem informasi.

\subsection{Perancangan Sistem Informasi}

Perancangan aplikasi berdasarkan permasalahan yang ada, yaitu bertujuan untuk memudahkan Servis Advisor, Admin Suku Cadang, dan Admin Keuangan untuk memperoleh informasi proses pekerjaan servis. Selain itu memberikan kemudahan tentang informasi rekapitulasi jasa dan entri kendaraan kepada manajer agar target perolehan jasa dan entri kendaraan yang dikerjakan oleh mekanik. Ada beberapa sistem informasi yang akan dibangun yaitu sebagai berikut:

a. Informasi kontrol proses kerja mekanik kepada servis advisor.

b. Informasi penggantian suku cadang kepada service advisor dan admin suku cadang.

c. Informasi tambahan pekerjaan mekanik kepada servis advisor.

d. Informasi rekapitulasi perolehan jasa mekanik kepada manajer secara uptudate.

\subsubsection{Diagram flow sistem informasi pekerjaan mekanik}

Aliran diagram dimulai dari pelanggan melakukan registrasi berupan data pribadi dan kendaraan kemudian dari servis advisor menerima keluhan dan menganalisa kendaraan kemudian membuat work order selanjutnya work order didistribusikan kepada Mekanik dan Suku Cadang. Pada proses pekerjaan mekanik akan membuat laporan (report) berupa tahapan proses dan penggantian suku cadang. Laporan ini akan diinput mekanik ke dalam sistem informasi, sehingga 
informasi ini akan dapat di akses secara langsung ke servis advisor dan suku cadang. Proses ini memungkinkan informasi cepat tentang proses pekerjaan kendaraan apabila pelanggan menanyakan.

Langkah selanjutnya kendaraan masuk pada tahapan selesai maka servis advisor akan memberikan input biaya jasa dan suku cadang, memberikan input pembelian suku cadang kemudian akan disampaikan kepada pelanggan dan pelanggan melakukan pembayaran di kasir. Di kasir akan terjadi proses input validasi status invoice yang telah dibayarkan. Pada sistem informasi akan diolah berupa tabel laporan perolehan jasa setiap mekanik dan jumlah kendaraan yang dikerjakan. Data ini akan diakses oleh manajer bengkel agar dapat memonitor kinerja mekanik yang ada. Diagram flow sistem informasi pekerjaan mekanik dapat di lihat pada Gambar 4.

\subsubsection{Context diagram (DFD Level 0)}

Context Diagram dari sistem informasi pekerjaan mekanik di Gama Auto Service ada
1 external entity yaitu Mekanik dan Pelanggan. Aliran datanya saling terkait satu sama lain. context diagram yang menjelaskan konteks diagram sistem secara umum hubungan antar entity dapat di lihat pada Gambar 5.

\subsubsection{Data flow diagram level 1}

Hasil pembagian (decompose) ini disebut DFD level 1, DFD level 1 ini terdiri dari 4 proses utama, 5 external entity dan 6 data store yang saling berkaitan. DFD level 1 ini dapat dilihat pada Gambar 6.

\subsubsection{Entity Relationship Diagram (ERD) \\ Entity Relationship Diagram (ERD) merupakan proses yang menunjukan hubungan antar entitas dan relasinya. ERD tahapan ada dua yaitu Conceptual Data Model dan Phsycal Data Model. Secara lengkap dapat dilihat pada Gambar 7 dan 8 .}

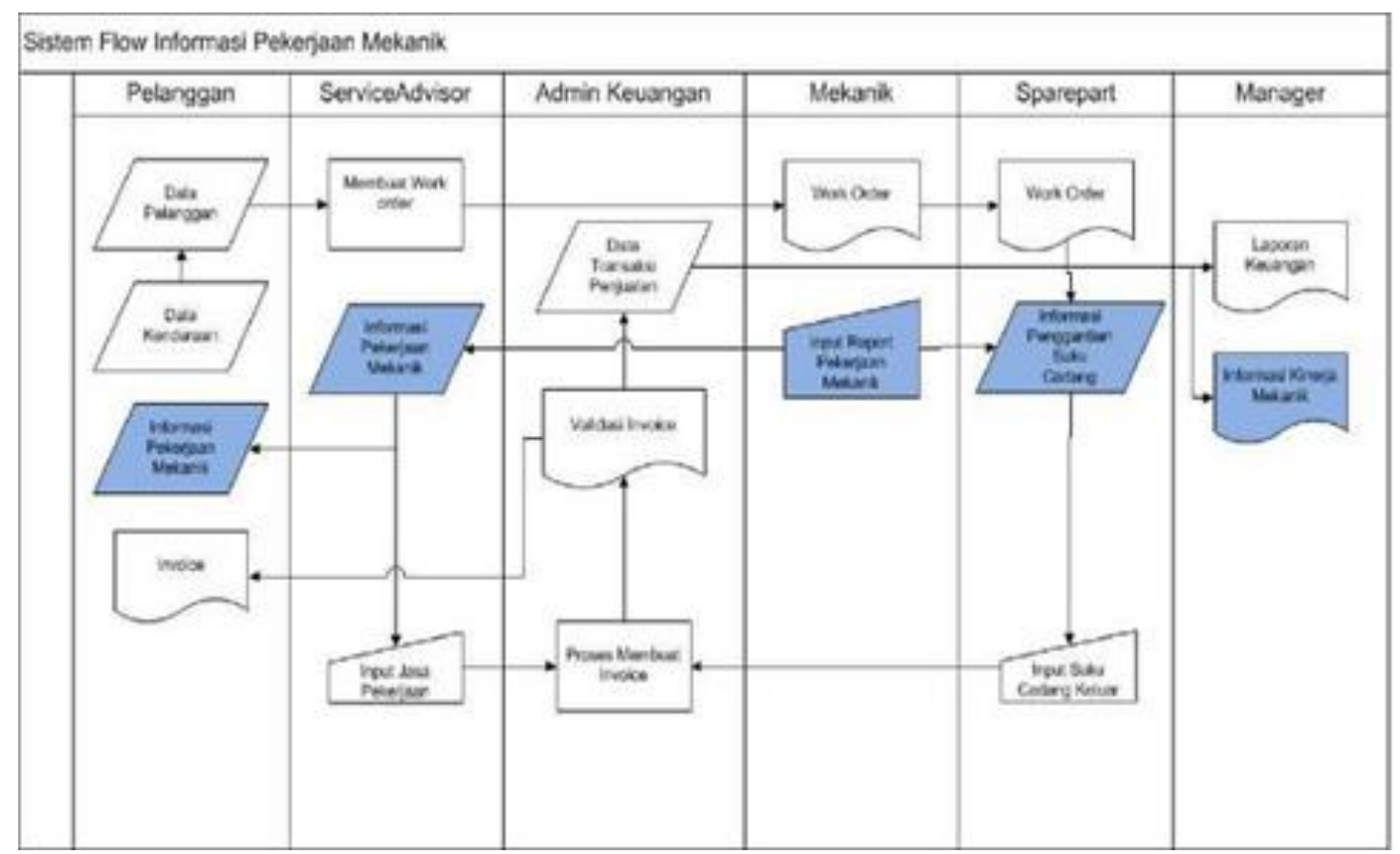

Gambar 4. Diagram Flow Sistem Informasi Pekerjaan Mekanik 


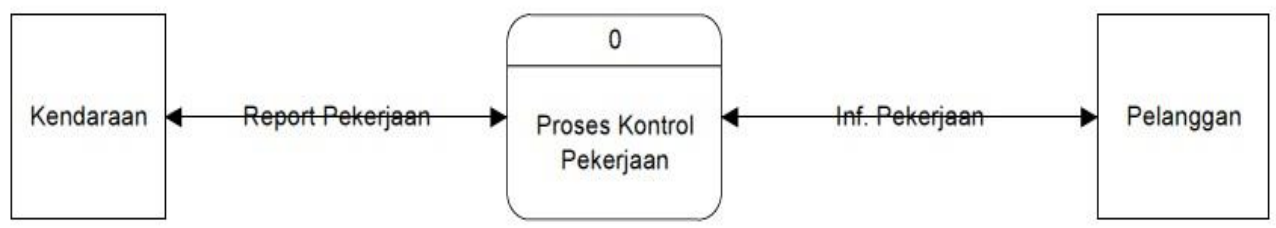

Gambar 5. Context Diagram Sistem Informasi Pekerjaan Mekanik

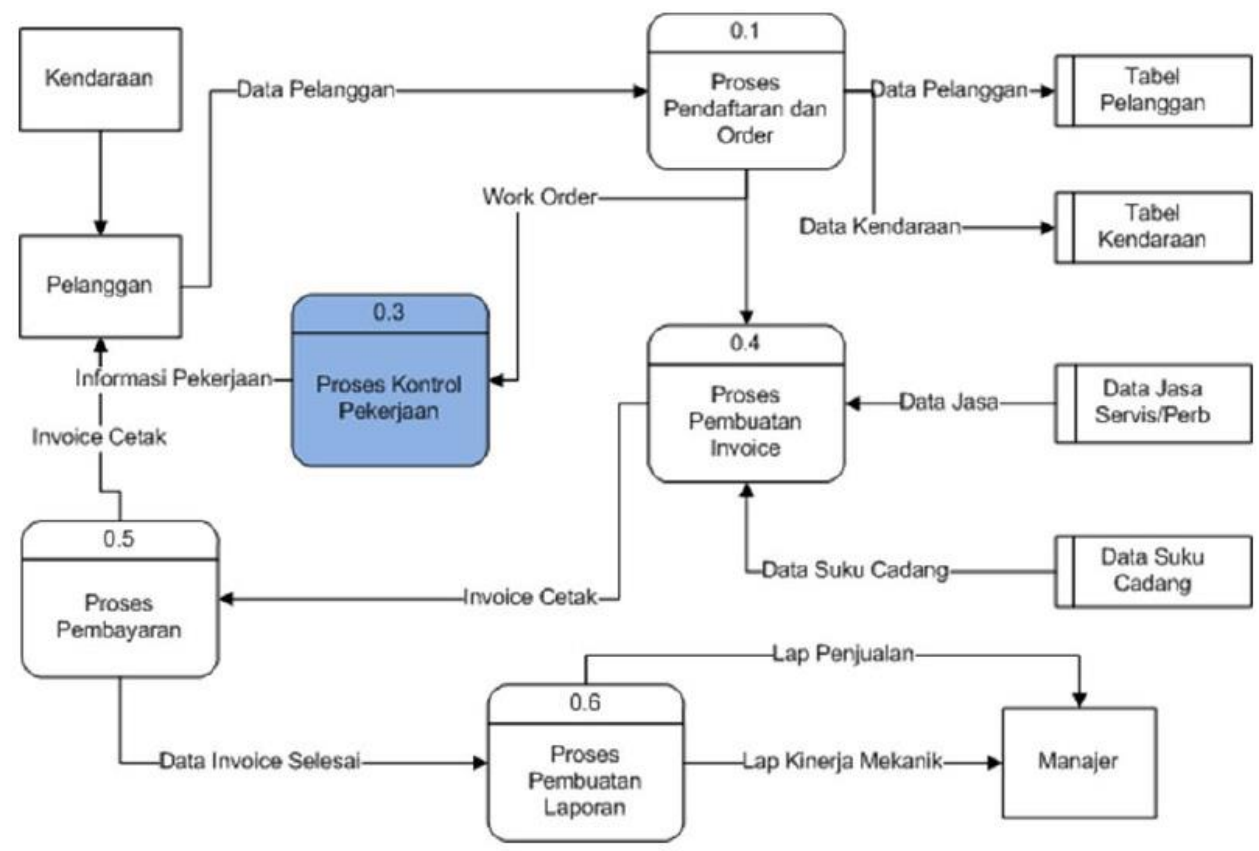

Gambar 6. Data Flow Diagram Level 1 Sistem Informasi Kontrol Pekerjaan Mekanik

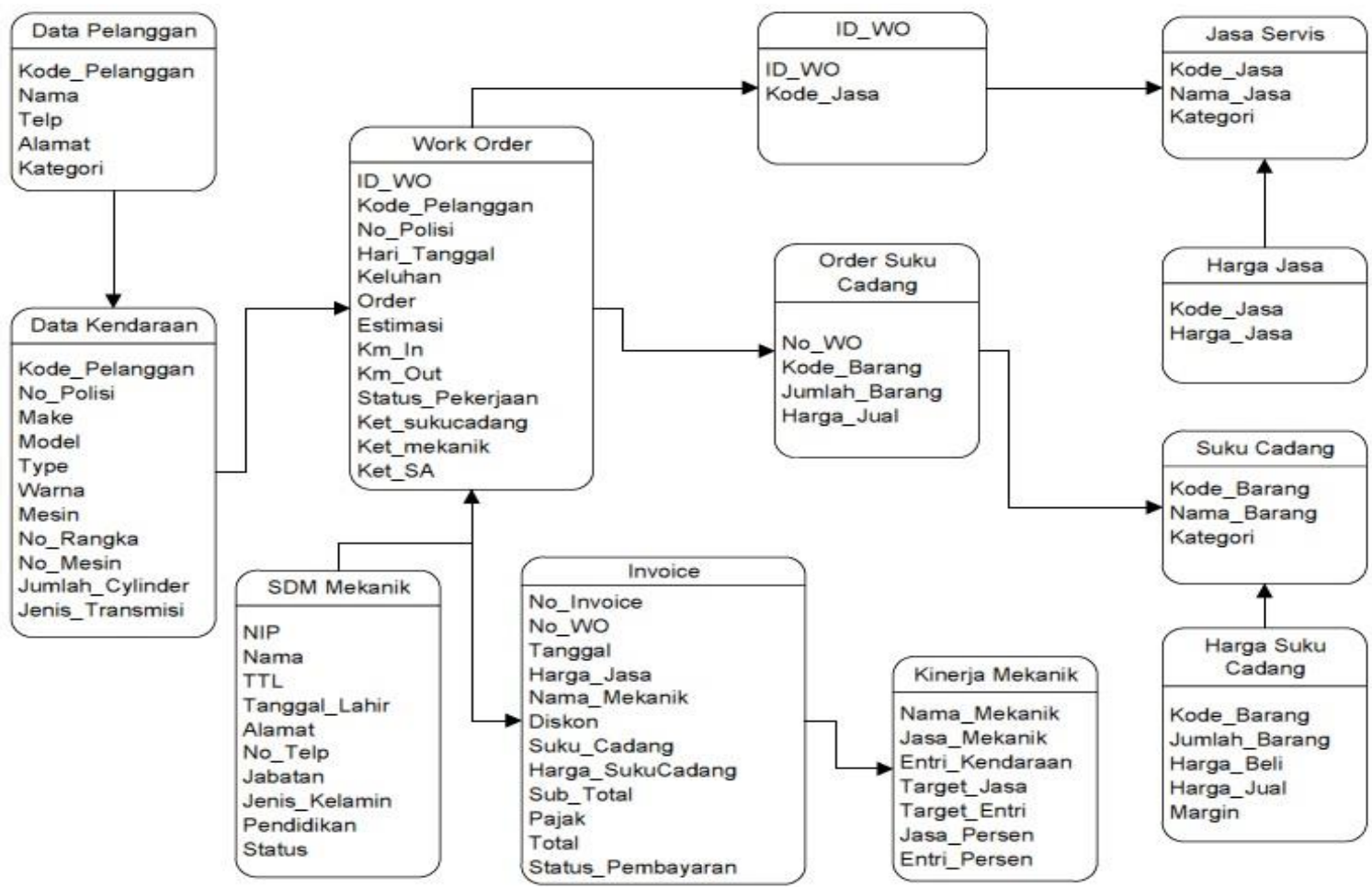

Gambar 7. Conceptual Data Model 


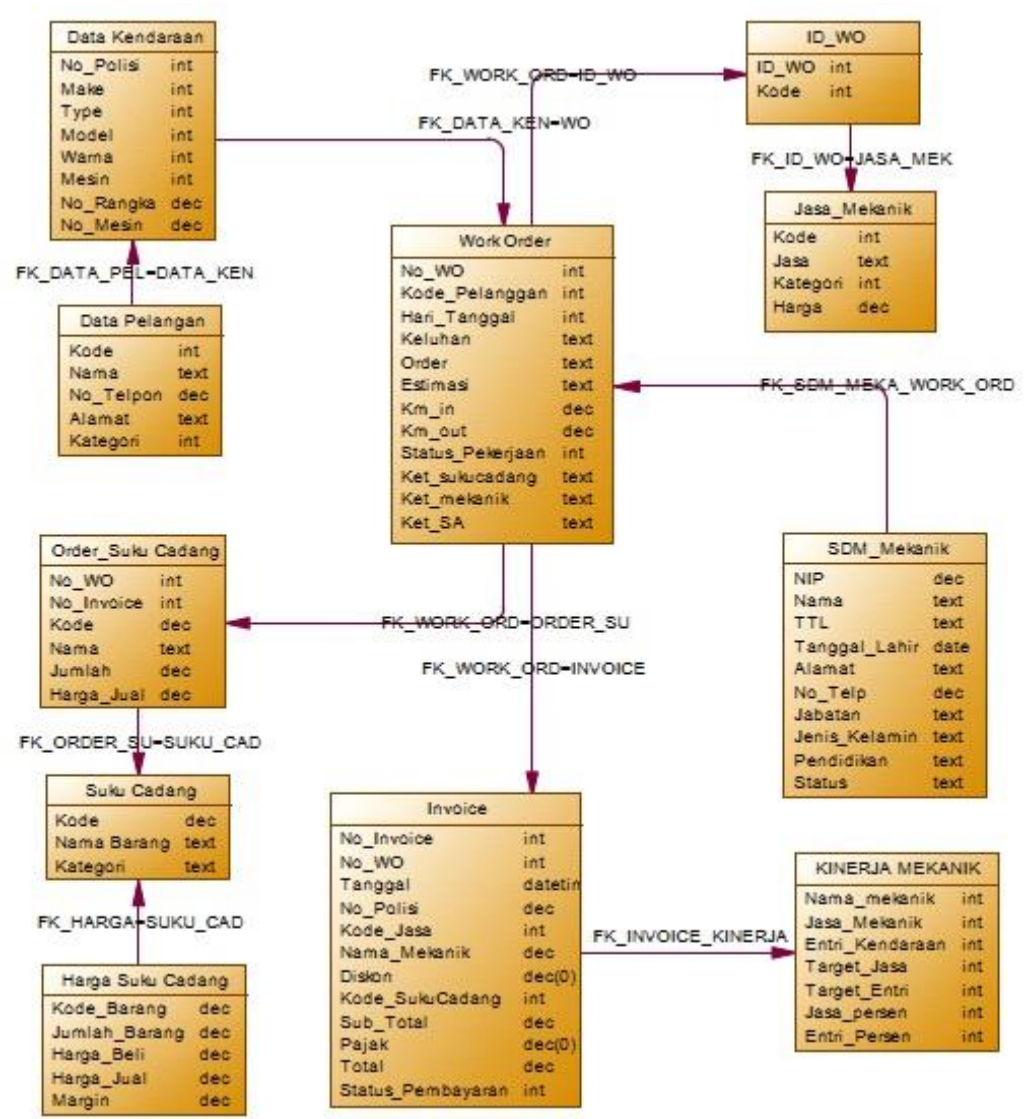

Gambar 8. Physical Data Model

\subsubsection{Struktur tabel}

Berikut ini akan dijelaskan table-tabel yang digunakan dalam perancangan.

a.Tabel Login

Nama Tabel : Login

Primary key : Kode_Pemakai

Keterangan : Tabel ini berisikan datadata untuk mendapatkan hak akses untuk login ke sistem.

Tabel 1. Tabel Login

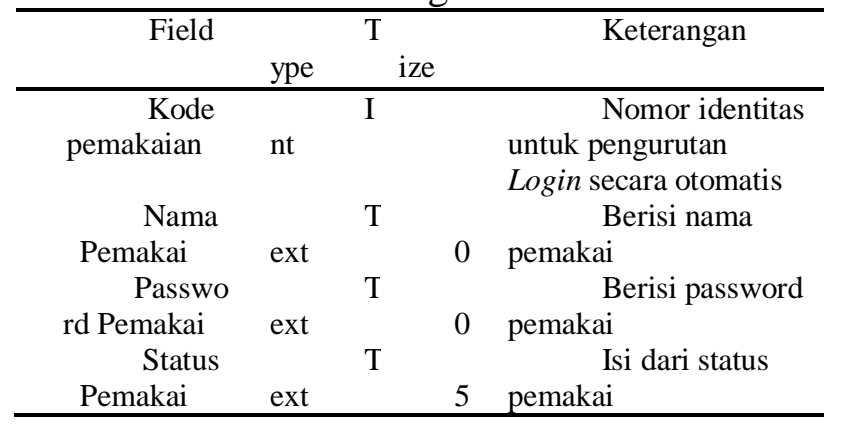

b. Tabel Registrasi

Nama table : Registrasi

Primary key : Kode_konsumen
Keterangan: Tabel ini berisi data konsumen.

Tabel 2. Tabel Registrasi

\begin{tabular}{|c|c|c|c|c|}
\hline \multirow[t]{2}{*}{ Field } & \multicolumn{3}{|c|}{ Тур } & \multirow[t]{2}{*}{ Keteranga } \\
\hline & $\mathrm{e}$ & & ize & \\
\hline Kode_Pel & & in & & Nomor \\
\hline anggan & $\mathrm{t}$ & & 1 & $\begin{array}{l}\text { identitas untuk } \\
\text { pengurutan } \\
\text { nomor konsumen } \\
\text { secara otomatis. } \\
\text { xxxxxxxxxxx = } \\
\text { kategori } \\
\text { konsumen, tahun } \\
\text { registrasi, bulan, } \\
\text { tanggal, nomor } \\
\text { urut }\end{array}$ \\
\hline Nama & & $\mathrm{T}$ & & Berisi \\
\hline Konsumen & ext & & 0 & nama konsumen \\
\hline Telepon & & $\mathrm{N}$ & & Nomor \\
\hline Konsumen & umber & & $\mathrm{nt}$ & telepon konsumen \\
\hline Alamat & & $\mathrm{T}$ & & Berisi \\
\hline Konsumen & ext & & 0 & $\begin{array}{l}\text { alamat lengkap } \\
\text { konsumen }\end{array}$ \\
\hline Kategori & & te & & Kategori \\
\hline Konsumen & $\mathrm{xt}$ & & 5 & $\begin{array}{l}\text { UGM, Instansi } \\
\text { Negeri, Instansi } \\
\text { Swasta, Umum. }\end{array}$ \\
\hline
\end{tabular}


c.Work Order

Nama table : Work_order

Primary key : No_WO

Keterangan : Tabel ini berisi keluhan pelanggan dan gambaran pekerjaan yang akan dilakukan.

Tabel 3. Work Order

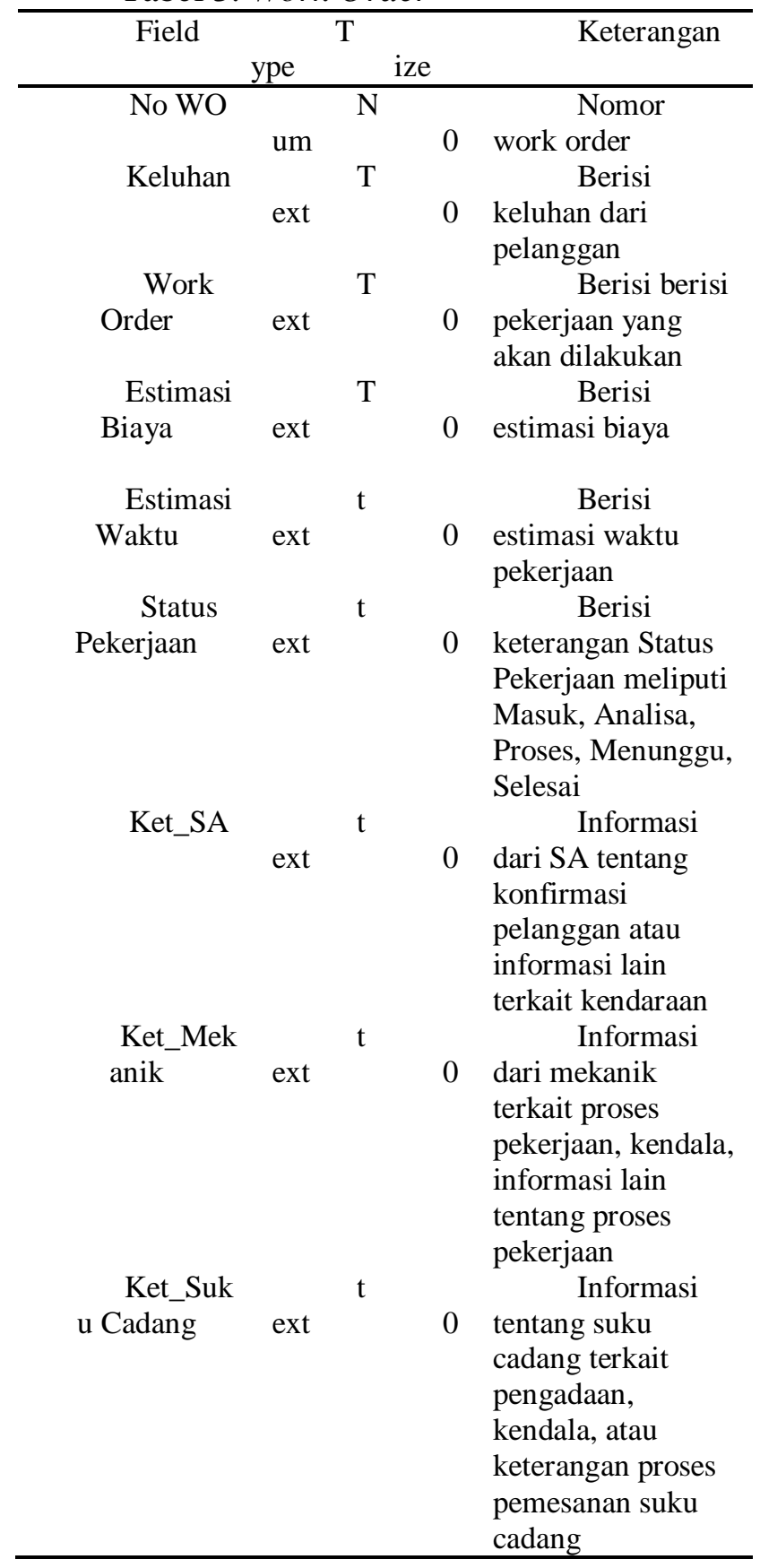

\section{d. Data Kendaraan}

Nama table : Data_kendaraan

Primary key : No_Polisi

\section{kendaraan}

Keterangan :Tabel ini berisi data

Tabel 4. Data Kendaraan

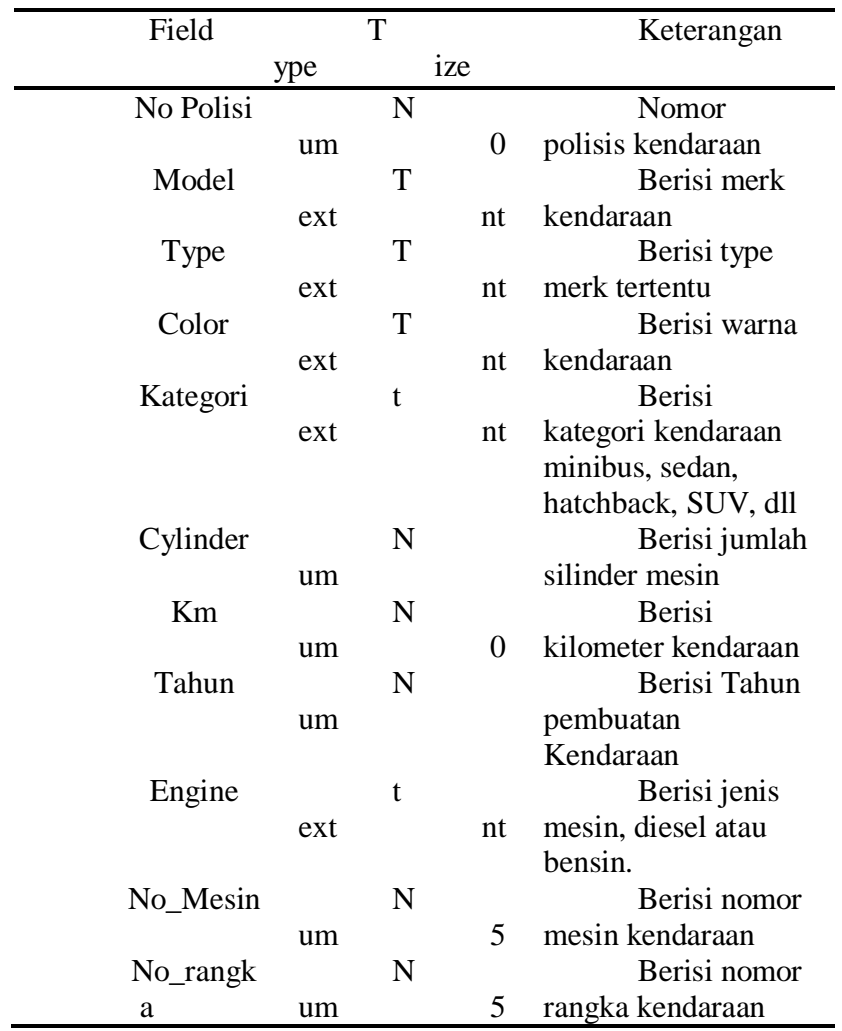

e.Report transaksi

Nama table : report_transaksi

Primary key : No_invoice

Keterangan : Tabel ini berisi laporan transaksi penjualan

Tabel 5. Report Transaksi

\begin{tabular}{|c|c|c|c|}
\hline \multirow[t]{2}{*}{ Field } & \multicolumn{2}{|r|}{ T } & \multirow[t]{2}{*}{ Keterangan } \\
\hline & ype & ize & \\
\hline No & & $\mathrm{n}$ & Nomor invoice \\
\hline Invoice & um & 0 & \\
\hline Kode & & $n$ & Berisi kode jasa \\
\hline Jasa & um & 0 & service \\
\hline Nam & & $\mathrm{T}$ & Berisi nama jasa \\
\hline a_jasa & ext & nt & service \\
\hline Harg & & $\mathrm{n}$ & Berisi nominal \\
\hline a & um & 0 & harga jasa service \\
\hline Juml & & $\mathrm{n}$ & Berisi nominal \\
\hline ah & um & & jumlah service \\
\hline Nam & & $\mathrm{T}$ & Berisi nama \\
\hline a Mekanik & ext & nt & $\begin{array}{l}\text { mekanik yang } \\
\text { mengerjakan }\end{array}$ \\
\hline
\end{tabular}

f. Informasi Jasa dan Entri Kendaraan

Nama table : Informasi_jasa mekanik 
Primary key : Jasa_Mekanik

Keterangan : Tabel ini berisi informasi rekap pekerjaan mekanik dan jumlah kendaraan

Tabel 6. Informasi Jasa Mekanik

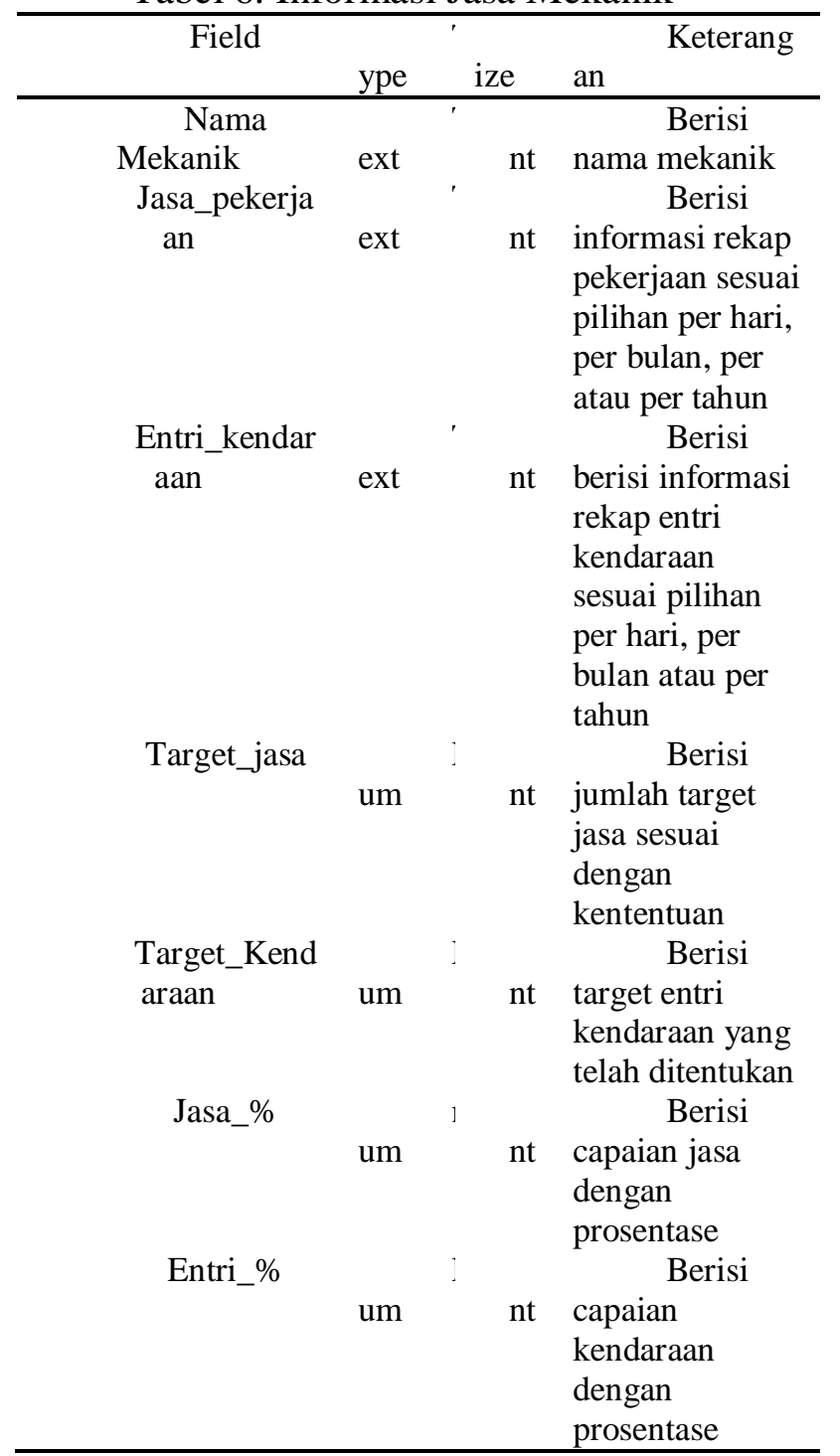

\subsubsection{Desain interface}

Desain Interface merupakan langkah pertama untuk membuat sebuah aplikasi sistem informasi. Pada tahap ini pengguna akan diberikan gambaran tentang bagaimana visualisasi dari aplikasi yang akan dibuat.

a. Desain input

Pada tahapan ini akan dilakukan peran cangan antar muka (interface) yang berfungsi sebagai perantara antara pengguna sistem dengan sistem itu sendiri (Rahadi, 2014).
Desain input adalah gambaran secara umum tentang visualisasi dari aplikasi yang akan dibuat, antara lain:

\section{Desain Halaman Antrian}

Desain input form halaman antrian kendaraan servis sekaligus sebagai halaman informasi proses pekerjaan sebagai kontrol pekerjaan. Meliputi tampilan data antrian kendaraan dan informasi pekerjaan dari SA, Mekanik dan suku cadang. Selain itu halaman ini dilengkapi pencarian kendaraan, desain dapat dilihat pada Gambar 9.

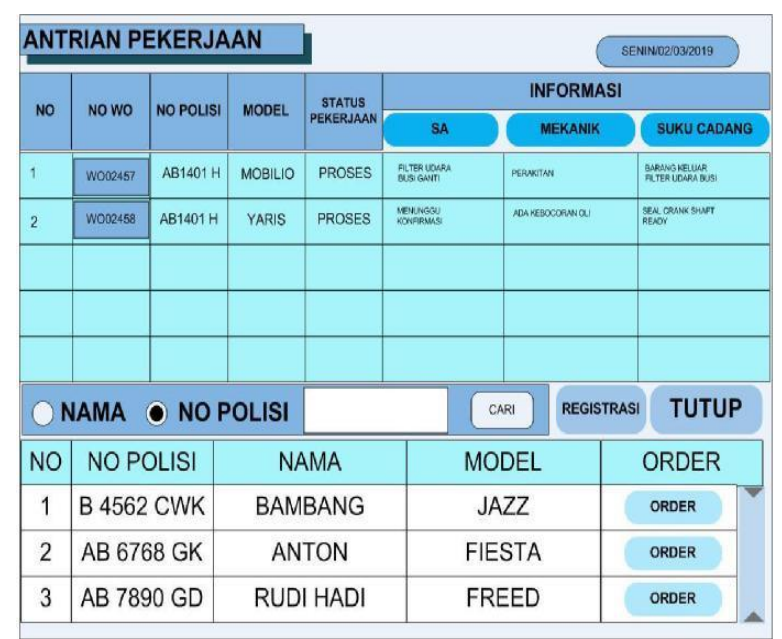

Gambar 9. Desain Interface Antrian Pekerjaan

Pada Gambar 9 terdapat informasi proses pekerjaan yang akan di input oleh SA (Service Advisor), Mekanik, Suku Cadang, Registrasi dan Order. Masing masing bagian akan memberikan informasi setiap pekerjaan yang dilakukan yaitu proses berjalan, kendala atau keterangan lain yang dapat dituliskan di kolom masing-masing. Desain interface kolom Registrasi, Order, SA, mekanik, dan Suku Cadang dapat dilihat pada Gambar 10, 11, 12, 13, dan 14.

Gambar 10 adalah desain form pendaftaran atau registrasi yang berisi input data pelanggan dan kendaraan. Data pelanggan lengkap serta kategori pelanggan yang didesain meliputi pelanggan Umum (personal), UGM (civitas akademisi UGM), Institusi Negeri dan Institusi Swasta). Sedangkan data kendaraan merupakan spesifikasi kendaraannya. 
Gambar 11 adalah desain form Work Order yang berisi input keluhan konsumen Order Pekerjaan dan estimasi pekerjaan serta Report Pekerjaan. Selain itu juga dilengkapi data lengkap pelanggan dan kendaraannya.

Selanjutnya gambar 12, 13 dan 14 adalah form input mekanik, suku cadang dan servis advisor yang berisi no work order, nama pelanggan, no polisi, jenis kendaraan, status pekerjaan dan catatan atau informasi dari masing-masing divisi.

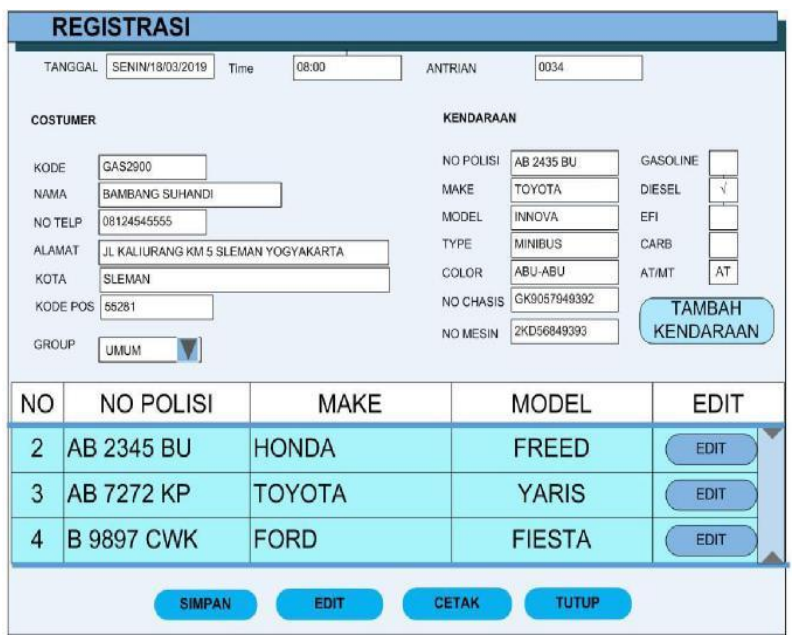

Gambar 10. Desain Interface Registrasi

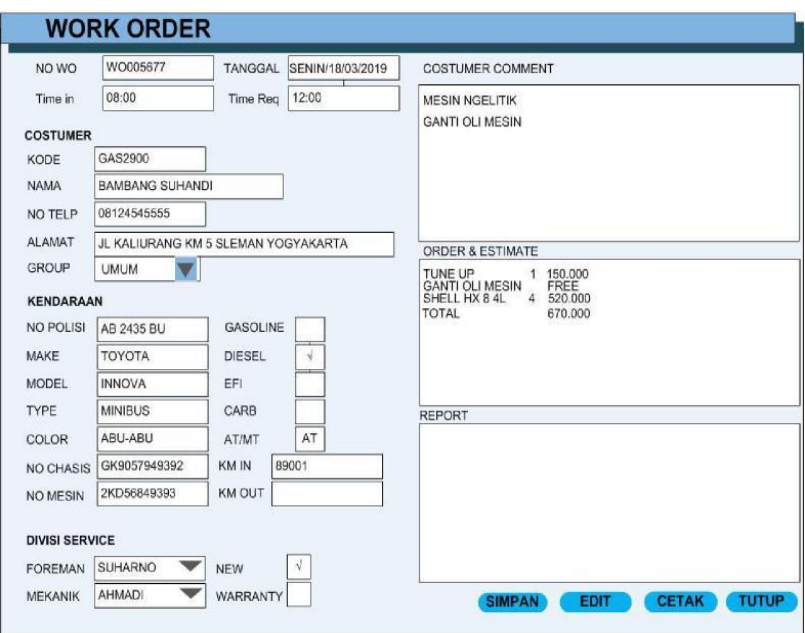

Gambar 11. Desain Interface Work Order

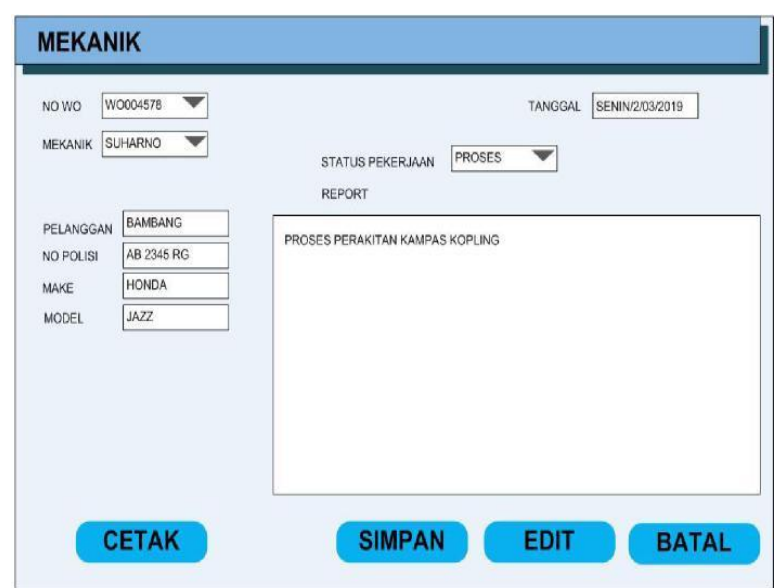

Gambar 12. Desain interface report mekanik

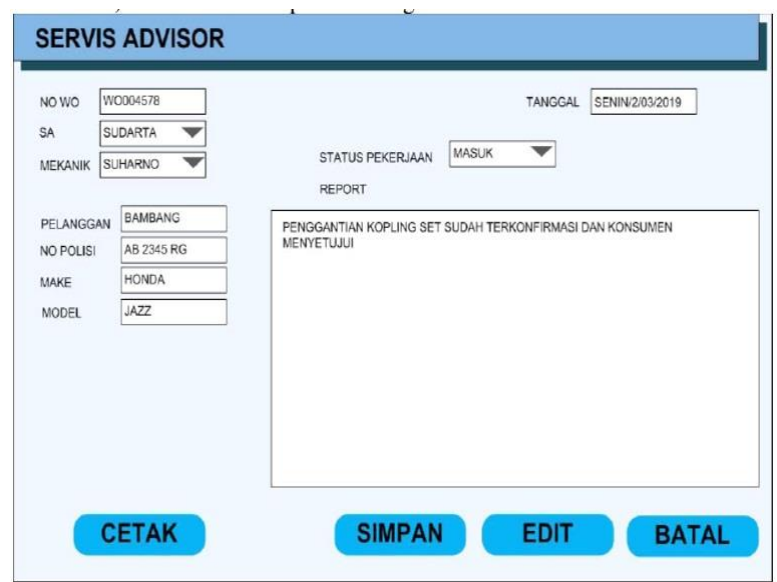

Gambar 13. Desain form input keterangan Service Advisor

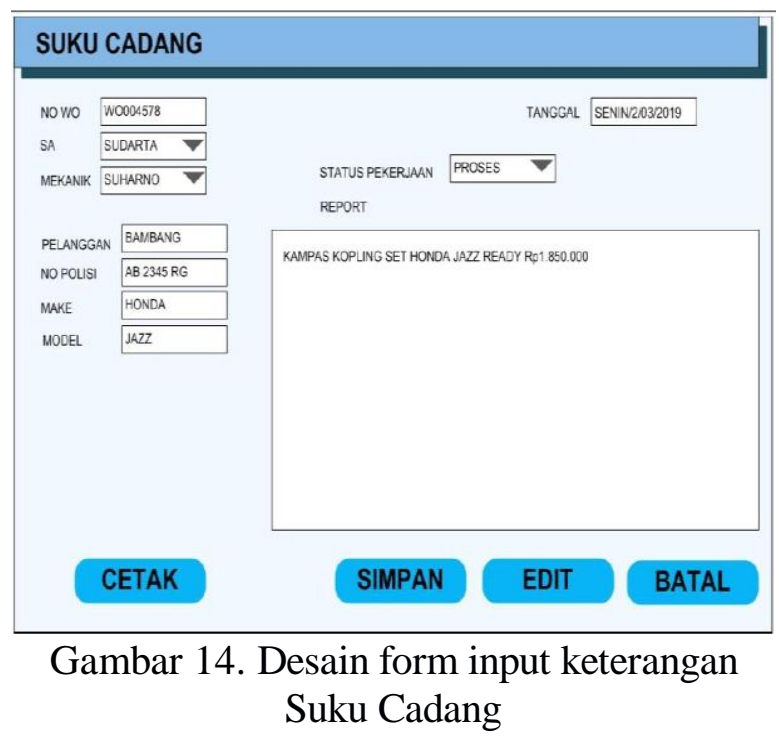


2. Desain Interface Capaian Kinerja

Desain interface merupakan desain antarmuka antara aplikasi yang akan di buat (Rizaludin, 2019). Format Kinerja merupakan form hasil capaian kendaraan yang dikerjakan beserta capaian jasa perbaikan. Format ini dibuat dengan tujuan memberikan informasi kepada Manajer untuk mengontrol capaian finansial perusahaan agar dapat sesuai dengan target perusahaan. Selain itu dengan dengan adanya format ini manager langsung mendapatkan informasi ter-update setiap harinya sehingga dapat segera mendapat informasi yang valid dalam mengambil kebijakan SDM, teknis maupun marketing. Format desain Capaian Kinerja dapat dilihat pada Gambar 15 dan 16.

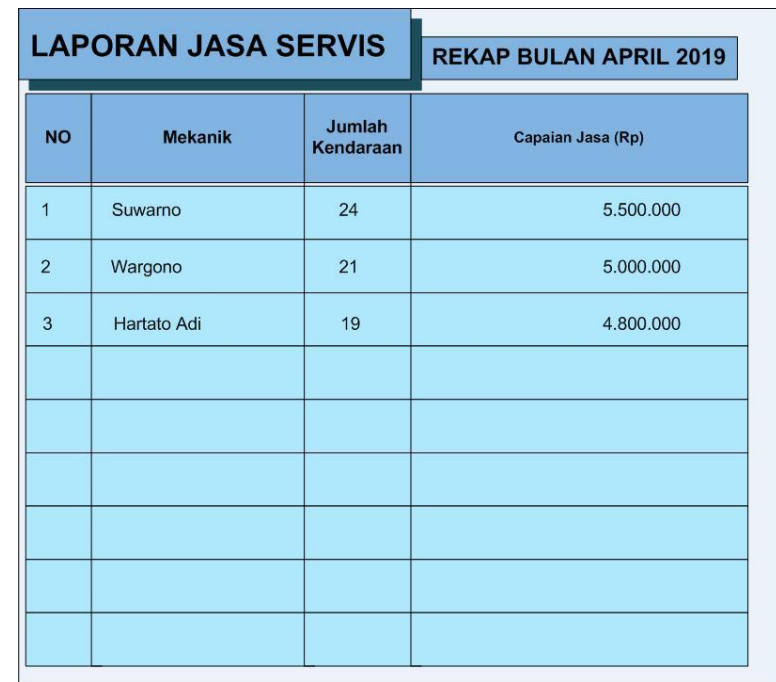

Gambar 15. Desain Interface Perolehan Jasa Servis

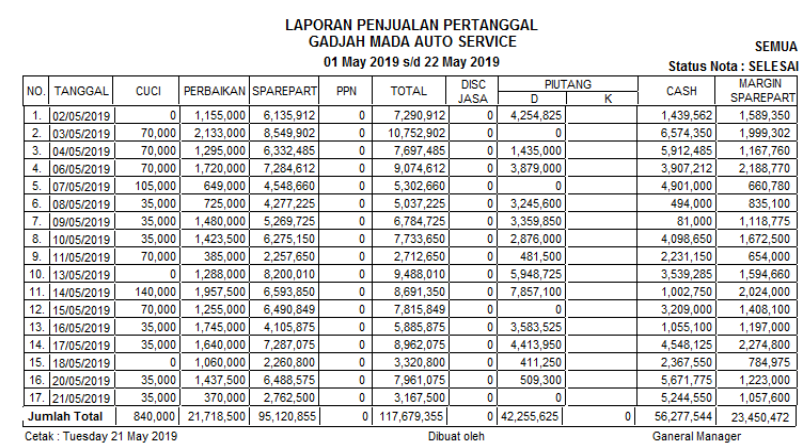

Gambar 16. Desain Laporan Pendapatan per Periode atau Setiap Hari

\section{Kesimpulan}

Sistem informasi kontrol pekerjaan harapannya dapat menjadi solusi permasalahan terhambatnya informasi pekerjaan dan dapat mempercepat informasi dari beberapa bagian di Divisi Servis. Selain itu secara internal, komunikasi antar divisi yang baik dan terkontrol akan membangun hubungan yang solid antar divisi dan dapat meningkatkan pendapatan perusahaan.

Dengan sistem informasi kontrol pekerjaan komunikasi dengan pelanggan juga akan lebih cepat sehingga dapat meningkatkan pelayanan konsumen serta menghindari salah informasi terhadap konsumen. Sehingga dapat mengurangi tingkat complain dari konsumen perihal komunikasi.

\section{Daftar Pustaka}

Aswati, Safrian, dkk. (2016). Model Rapid Application Development dalam Rancang Bangun Sistem Informasi Pemasaran Rumah (Studi Kasus : Perum Perumnas Cabang Medan). Seminar Nasional Sistem Informasi Indonesia. Hal 318 - 324.

Daryanto. (2006). Teknik pemeliharaan mobil: pemeriksaan dan perbaikan. Jakarta: Bhumi Aksara.

Desy, F.T \& Lia Yong. (2010). Sistem Informasi Manajemen Penjualan, Persediaan dan Servis pada Dealer Jaya Perkasa Motor. Palembang: STMK GI MDP.

Desy, F.T \& Lia Yong. (2010). Sistem Informasi Manajemen Penjualan, Persediaan dan Servis pada Dealer Jaya Perkasa Motor. Palembang: STMK GI MDP.

Jogiyanto. (2005). Analisis \& Desain Sistem Informasi. Yogyakarta: Andi.

Kendall, J.E. \& Kendall, K.E. (2010). Analisis dan Perancangan Sistem. Jakarta: Indeks.

Kurniawan, Helmi. (2015). Perancangan Sistem Informasi Bengkel Mobil 
Berbasis Web. Konferensi Nasional Sistem \& Informatika. Hal 637-641).

Marakas, G.M. (2006). System Analysis Design an Active Approach. New York: Mc.Graw-Hill.

Mc.,Leod, R. Jr. (2002). System Development A Project Management Approach. New York: Leigh Publishing LLC.

Nurdiana, D. 2009, "Kamus Digital (InggrisIndonesia/Indonesia-Inggris) Berbasis SMS Gateway", Prosiding Seminar Program Studi Ilmu Komputer, Universitas Pendidikan Indonesia

O'Brien, James. (2005). Pengantar sistem Informasi: Perspektif Bisnis dan Manajerial. Edisi ke-12 terjemahan Dewi Fitiriasari dan Deny Arnos Kwary (2012). Jakarta: Salemba Empat.

Pressman, R.S. (2012). Rekayasa Perangkat Lunak: Pendekatan Praktisi. Yogyakarta: Penerbit Andi.

Rahadi, Adysta. (2014). Analisis dan Desain Sistem Informasi Persediaan Barang Berbasis Komputer. Jurnal Administrasi Bisnis (JAB). Vol 8 (2). Hal $1-8$.

Ramadina, Syahrina. (2015). Pengembangan Sistem Informasi Menejemen Bengkel Kerja Sekolah Menengah Kejuruan. Jurnal Pendidikan Vokasi. Vol 5 (1) Hal 103-116.

Riyadi, Anggiani Septima. Dkk. (2012). Perencanaan Sistem Informasi berbasis Website Subsistem Guru di Sekolah Pesantren Persatuan Islam 99 Rancabango. Jurnal Algoritma Sekolah Tinggi Teknologi Garut. Vol 1.09 (2). Hal 237-337.

Rizaludin, Darian. Dkk. (2019). Massage Queuing Telemetry Transport dalam Internet of Things Menggunakan ESP32. Jurnal Media Informatika Budidarma. Vol 3 (3). Hal 159 -180.

Sebayang, Desi. (2015). Perancangan Sistem Inforamsi Bengkel Mobil Palapa.Yogyakarta: Amikom.

Teiseran, Martin T. (2003). Merawat dan Memelihara Mobil. Yogyakarta: Kanisius.
Tim KSS. (2007). Mengelola Bengkel Mobil, Dinamika. Jakarta: Media.

Ward, J. \& Peppard, J. 2003, Strategic Planning For Information System, 3 rd Edition, John Wiley \& Son, Chicester, USA

Winardi, dkk. (2017). Rancang Bangun Sistem Informasi Manajemen Bengkel (Study Kasus: CV. Anugrah Bogor). Indonesian Journal on Software Engineering. Vol 3 (2) Hal 8-14. 